\title{
Autumn 1995 Examinations timetable
}

\begin{tabular}{|c|c|c|}
\hline $\begin{array}{l}\text { Mreprych } \\
\text { Examinations }\end{array}$ & $\begin{array}{l}\text { Port I } \\
\text { Autumn } 1996\end{array}$ & $\begin{array}{l}\text { Port II } \\
\text { Aculumn } 1996\end{array}$ \\
\hline Application forms available from & 8 May 1995 & 30 May 1995 \\
\hline Closing date for receipt of applications & 28 June 1995 & 19 July 1995 \\
\hline Written paper(s) & 10 October 1995 & 25 October 1995 \\
\hline Clinical ( $\&$ Oral) examinations during the week of & 16 October 1995 & 6 November 1995 \\
\hline FEES & $\$ 330$ & $\$ 390$ \\
\hline Results malled out & 8 November 1995 & 12 December 1995 \\
\hline Results displayed on College board & 9 November 1995 & 13 December 1995 \\
\hline
\end{tabular}

Late applications of up to one week after the official closing date will be allowed on payment of a non-refundable fee of $\{50.00$ sterling.

1. For application forms, please write or fax the Examinations Department, Royal College of Psychiatrists, 17 Belgrave Square, London SWIX 8PG, fax: Examinations, 071245 1231. Do not telephone for forms.

2. Notfication of withdrawal from the examinations must be recelved in writing. Withdrawal by telephone will not be accepted.

3. The College does not transfer application or fees from one examination to another.

4. Candidates who withdraw before the closing date for receipt of entries will be charged an administrattve fee of half the set fee paid.

5. Candidates who withdraw after the closing date for receipt of entries will not be elligible for a refund.

6. Candidates who fall to attend the examination on the days of the Examination will not be eligible for a refund.

7. Results are never given over the telephone.

\section{Obituaries}

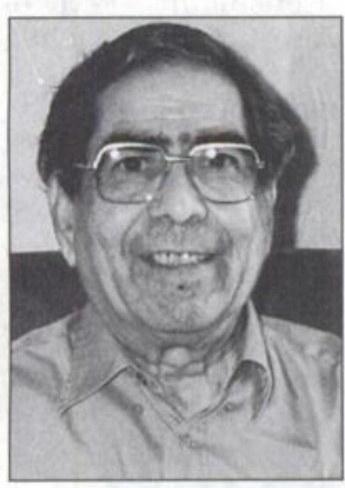

Milton Cedric Mons, formerly Senior Consultant Psychiatrist, Kingsmill and Newstead Hospital, Nottinghamshtre

Milton died at home on 15 November 1994 after a very short and painful illness which he bore bravely and with his customary

fortitude. He was sustained by his Roman Catholic falth and the loving support of his wife and daughter.

Milton was born at Bangalore, South India, on 20 December 1924, the eldest of a family of nine. He received his education at Bishop Cotton High School, Bangalore, before studying mediche at Andhra Untversity where he graduated MB BS in 1950. After a post as House Officer in India he served with distinction in the Indian Army Medical Corp from 1952-1957.

On leaving the Army he came to Britain and was appointed SHO in general duties at Clacton Hospital where he met his wife to be, 
a qualified nurse. Having developed an interest in psychiatry he was appointed Registrar, later Junior Hospital Medical Officer at Deva Hospital, Chester from 1957-1960 and then Senior Registrar to Moorhaven Hospital, Devon from 1960-1962. He gained the DPM (Eng) in 1959. He had a special interest in alcoholism, becoming a Research Fellow with the status of Senior Registrar to Addenbrooke's Hospital, Cambridge from 1962-1965 and published papers on 'Psychiatric first admissions from Cambridgeshire;' and 'Alcoholism in an English County'. He then obtained his consultant post at the Ashfield Clinic, Kingsmill Hospital, Nottinghamshire and Saxondale Hospital, Nottinghamshire. He was elected MRCPsych in 1971 and proceeded to the fellowship in 1983.

He was instrumental in developing an excellent and widespread psychiatric service in the Mansfield area - one of the first to be based on a general hospital. As a result of this responsibility he gained the respect of both his medical and surgical colleagues which led to various administrative appointments - the Mansfield Hospital Management Committee, Central Notts Management Team, Chairman of Central Notts Psychiatric Division and Chairman of Nottingham Area Psychiatric Division and others. Latterly, before his retirement in spring 1988, he developed a comprehensive psychogeriatric service at Newstead Hospital.

Milton was a quiet, kindly individual, much loved by his patients and colleagues, always willing to share a problem and give advice. His was a close-knit family with whom he kept in contact by visits to India and Australia where his siblings lived.

He is survived by his wife Monica and his daughter Julia, who is medically qualified and pursuing her great interest in psychiatry.

E. G. ORAM

David Perk, formerly Honorary Senior Psychiatrist, Tara Hospital, Johannesburg, South Africa

David Perk died on 29 January 1994 in his 91st year. He was born in Lithuania on 19 March 1903 and emigrated with his family to South Africa.

He came to England and studied medicine at Leeds, graduating $\mathrm{MB} \mathrm{ChB}$ in 1925, and proceeded to the MD in 1930.
Having decided on a career in psychiatry he was appointed Assistant Medical Officer at the West Riding Mental Hospital, Menston near Leeds and later at the Gloucester Mental Hospital. He gained the DPM (Leeds) in 1928 and was elected to the Foundation Fellowship of the College in 1971.

Perk's interest lay mainly in psychotherapy and to this end he came to London where he was appointed honorary psychotherapist at the Maudsley. In addition he held other honorary appointments at the British Hospital for Functional Mental and Nervous Disorders and the West London Hospital. During the 1939-45 War he served as a captain in the RAMC.

After war service he returned to South Africa where he was appointed Senior Psychiatrist to the Tara Hospital and as Clinical Tutor at the Witwatersrand University, Johannesburg.

Perk was a prolific writer, his main publications being philosophically inclined as, for example, his Man's Quest for Meaning, Faith and Identity and The Mystery of the Human Mind.

He married in 1950 and had two daughters, Vivienne and Margot.

\section{The deaths of the following have also been reported:}

JOHN ARTHUR NICHOLAS CORSELLIS, retired; formerly Professor of Neuropathology, Institute of Psychiatry, London.

JACK Lews Evans, Consultant Psychiatrist, 1/46 Centre Road, Brighton East, Victoria 3187. Australia.

HANS AXEL FORSSMAN, Emeritus Professor, Psychiatric Research Centre, St Jorgans Hospital, Sweden.

HENRY LAUTCH, retired Consultant Psychiatrist, Burton Road Hospital, Dudley, West Midlands.

MaUd NORMan-NoTt, Consultant Psychotherapist, Royal Hampshire County Hospital, Winchester.

Eu RoBINS, Professor of Psychiatry, Washington University School of Medicine, St Louis, Missouri 63110, USA.

JOHN DONALD RUSSELL, Consultant Psychiatrist, Health Commission of New South Wales, Sydney, Australia.

GERTRUDE SMITH, retired; 16 Dorchester Drive, London SE24.

DAVID WAXMAN, Private Practice, 23 Harley Place, London W1. 